\title{
TECHNOLOGY, FACTOR SUPPLIES AND \\ INTERNATIONAL SPECIALIZATION: \\ ESTIMATING THE NEOCLASSICAL \\ MODEL
}

\author{
James Harrigan
}

Working Paper 5722

\author{
NATIONAL BUREAU OF ECONOMIC RESEARCH \\ 1050 Massachusetts Avenue \\ Cambridge, MA 02138 \\ August 1996
}

This paper has benefitted from the comments of my former colleagues at the University of Pittsburgh and seminar participants at the NBER Summer Institute, Rutgers, Purdue, British Columbia, Harvard, the Federal Reserve Bank of New York, Penn State, and Princeton. James Cassing helped greatly in the development of the ideas used in this paper, and two anonymous referees were instrumental in improving it. This paper is part of NBER's research program in International Trade and Investment. Any opinions expressed are those of the author and not those of the Federal Reserve Bank of New York, the Federal Reserve System, or the National Bureau of Economic Research.

(C) 1996 by James Harrigan. All rights reserved. Short sections of text, not to exceed two paragraphs, may be quoted without explicit permission provided that full credit, including $\odot$ notice, is given to the source. 


\title{
TECHNOLOGY, FACTOR SUPPLIES AND \\ INTERNATIONAL SPECIALIZATION: \\ ESTIMATING THE NEOCLASSICAL MODEL
}

\begin{abstract}
The standard neoclassical model of trade theory predicts that international specialization will be jointly determined by cross-country differences in relative factor endowments and relative technology levels. This paper uses duality theory combined with a flexible functional form to specify an empirical model of specialization consistent with the neoclassical explanation. According to the empirical model, a sector's share in GDP depends on both relative factor supplies and relative technology differences, and the estimated parameters of the model have a close and clear connection to theoretical parameters. The model is estimated for manufacturing sectors using a 20 year, 10 country panel of data on the OECD countries. Hicks-neutral technology differences are measured using an application of the theory of total factor productivity comparisons, and factor supplies are measured directly. The estimated model performs well in explaining variation in production across countries and over time, and the estimated parameters are generally in line with theory and previous empirical work on the factor proportions model. Relative technology levels are found to be an important determinant of specialization.
\end{abstract}

James Harrigan

Research Department

Federal Reserve Bank of New York

33 Liberty Street

New York, NY 10045

and NBER

james.harrigan@frbny.sprint.com 


\title{
Technology, Factor Supplies and International Specialization: Estimating the Neoclassical Model
}

\author{
James Harrigan \\ Federal Reserve Bank of New York ${ }^{1}$
}

July 1996

\section{Introduction}

In the neoclassical general equilibrium model of international trade, countries trade with each other because of their differences. Countries may differ in their preferences, their technologies, or their factor supplies, and these differences jointly determine comparative advantage and hence trade. Technology differences as a source of comparative advantage were first studied by Ricardo, who identified different relative labor productivities as the cause of trade, while Heckscher and Ohlin assumed away technology differences and focused on differences in relative supplies of capital and labor as the causes of trade. The Ricardian and Heckscher-Ohlin explanations have been generalized by post-war trade theorists, with the general factor proportions explanation encompassing many goods and factors while the generalized Ricardian explanation encompasses general technology differences. Modern theorists of course recognize that general technology and factor supply differences can jointly determine

\footnotetext{
' Research Department, 33 Liberty Street, New York, NY 10045, e-mail: james.harrigan@frbny.sprint.com, phone: (212) 720-8951, fax: (212) 720-6831. This paper has benefitted from the comments of my former colleagues at the University of Pittsburgh and seminar participants at the NBER Summer Institute, Rutgers, Purdue, British Columbia, Harvard, the Federal Reserve Bank of New York, Penn State, and Princeton. James Cassing helped greatly in the development of the ideas used in this paper, and two anonymous referees were instrumental in improving it. The views expressed in this paper are those of the author and do not necessarily reflect the position of the Federal Reserve Bank of New York or the Federal Reserve System.
} 
comparative advantage ${ }^{2}$. The purpose of this paper is to estimate just such a model, using data on technology, factor supplies, and production from a panel of industrialized countries.

While this has been the standard model of trade for many years, economists have spent little effort on empirical evaluation of the model, and most of the tests of the model have been inconclusive and/or unfavorable to the model, beginning with Leontief's famous paper on the trade of the United States (1954). Starting with Leamer (1984), a number of researchers have used theory in a careful way to evaluate general versions of the factor proportions explanation of specialization and trade, including Maskus (1985), Bowen, Leamer and Sveikauskas (1987), Staiger (1988), and Harrigan (1995). Each of these efforts has explicitly assumed identical technologies across countries, and the factor proportions model comes out looking to one degree or another seriously deficient in each case. An exception is Brecher and Choudhri (1993), who find that US-Canadian production patterns are consistent with the factor proportions approach. In an important recent paper, Trefler (1995) has evaluated a model where there are technology differences across countries which are common across sectors (or equivalently, factors). In Trefler's model, a technological improvement increases the effective supply of all factors proportionately. Since relative factor supplies are unchanged by neutral technological change, relative opportunity costs are not affected, and hence the pattern of comparative advantage remains determined solely by relative factor supplies. This simple extension of the factor proportions model works remarkably well. In particular, Trefler finds that the factor content of a country's net exports is approximately equal to its effective excess factor supplies.

\footnotetext{
${ }^{2}$ While recognized as a theoretical possibility, differences in tastes have only rarely been analyzed as a source of comparative advantage. An interesting exception is Markusen (1986) and Hunter and Markusen (1988).
} 
An unappealing aspect of Trefler's model is that relative factor prices and relative factor intensities are identical everywhere. This implies, for example, that the capital/labor ratio in Brazilian manufacturing is the same as the capital/labor ratio in Japanese manufacturing. Trefler's model also conflicts with direct evidence on relative technology differences by Dollar and Wolff (1993), van Ark and Pilat (1993), Jorgenson and Kuroda (1990), and Harrigan (1994a, 1994b). Dollar and Wolff provide some evidence that these relative productivity differences are related to differences in net export performance (in particular, their Section 7.3, pages 144-148).

As noted above, general versions of factor proportions theory have been subject to a fair amount of empirical scrutiny. In contrast, this author is not aware of any such efforts to evaluate general technology differences as sources of comparative advantage. This impression is bolstered by the surveys by Deardorff (1984) and Leamer and Levinsohn (1995), neither of which find any studies that evaluate general Ricardian explanations for trade, never mind any studies that look at the joint impact of technology and factor supply differences on specialization and trade. Dollar and Wolff (1993) do not formally address the influence of factor supplies on trade, but they do note that relative factor endowments interact with relative technology differences in determining comparative advantage, and suggest that considering these sets of influences together may help to better explain the pattern of trade (pg. 148).

One aim of this paper is to fill this gap in the empirical literature. The paper proposes an empirical model which is flexible enough to jointly estimate the impact of differing technologies and differing factor supplies on international specialization and trade. The model comes from applying a flexible functional form to the revenue function representation of the general equilibrium of the production sector, where there are Hicks-neutral technology differences across 
countries and over time. The model requires a minimal number of assumptions beyond the most basic ones (exogenous prices and factor supplies, competitive market clearing, no joint production, and constant returns to scale). This model is estimated on a data set of ten industrial countries over twenty years for seven different manufacturing sectors. Technology differences are measured by applying the theory of total factor productivity (TFP) comparisons to a data set on industry inputs and outputs, and factor endowments are measured directly. The empirical results show that technology differences are an important determinant of specialization, and that factor supplies alone cannot explain which industrial countries produce which goods. An implication of the results is that the factor proportions approach which has dominated much of the empirical and policy oriented research in the past may need to be replaced by a model which accounts for relative technology differences in addition to relative factor supply differences.

This paper does not provide a definitive test of the neoclassical model for two reasons. The first is that testing against a composite alternative in the classical statistical sense is inappropriate, since the neoclassical model is known to be a simplification of a complex world and is not intended to be taken as literally true. Second, it is not possible to test the neoclassical model against a well-specified alternative because there is no well-specified general equilibrium alternative model to which it can be compared. The most prominent alternative explanations for the pattern of international specialization include industry-level economies of scale (see Helpman, 1984, and Helpman and Krugman, 1985) and path-dependent geographical models (e.g., Krugman, 1991). However, these more recent models have not been integrated with the neoclassical literature so it is not possible to design a statistical model which precisely pinpoints the areas of disagreement between them and the neoclassical model. For these two reasons, the 
strategy of this paper is to follow Leamer and Levinsohn's (1995) sensible injunction to "estimate, don't test". The estimated model turns out to be statistically successful and generally in line with the predictions of theory, so the neoclassical model comes out looking rather well.

Section 2 of the paper briefly explains the theory of how Hicks-neutral technology differences influence outputs in general equilibrium, and outlines the dual representation of the economy's production sector as a function of prices, technology differences, and factor supplies. Section 3 develops the empirical model, and section 4 discusses data, measurement, and econometric issues. Section 5 presents the empirical results.

\section{Theory}

This section closely follows the standard treatments of Woodland (1982) and Dixit and Norman (1980). Consider a small open economy characterized by fixed aggregate factor supplies, constant returns to scale and competitive market clearing. As is well known, the general equilibrium of this economy will maximize the value of final output. A common formulation of this maximization problem is

$$
\text { Max p·x subject to } \mathbf{x} \in \mathbf{Y}(\mathbf{v}) \quad \mathbf{p}, \mathbf{x} \in \mathbb{R}^{N}, \mathbf{v} \in \mathbb{R}^{M}
$$

where $\mathbf{x}$ is the final goods vector, $\mathbf{p}$ is the vector of final goods prices and $\mathrm{Y}(\mathbf{v})$ is the convex production set for endowments $\mathbf{v}$. The solution to this problem gives the maximized value of GDP as $Y=r(p, v)$. As long as the revenue function $r(p, v)$ is twice continuously differentiable, which requires smooth substitutability among factors and at least as many factors as goods 
$(M \geq N)$, the vector of net output supplies $x(p, v)$ is given by the gradient of $r(p, v)$ with respect to $\mathbf{p}^{3}:$

$$
\mathbf{x}_{j}(\mathbf{p}, \mathbf{v})=\partial r(\mathbf{p}, \mathbf{v}) / \partial \mathbf{p}_{j} \quad j=1, \ldots, N
$$

Hicks-neutral technological differences across countries and/or time can be modeled easily using an extension of the dual approach. In addition to the standard assumptions on the revenue function, suppose that there exists a production function for each good given by

$$
\bar{x}_{j}=\theta_{j} \cdot f\left(v^{j}\right)=\theta_{j} x_{j} \quad j=1, \ldots, N
$$

where $\theta_{j}$ is a scalar parameter relative to some base period and/or country, and $\mathbf{v}^{\mathrm{j}} \in \mathbb{R}^{\mathrm{M}}$ is a vector of inputs. The assumption of the existence of distinct production functions implies that joint production is ruled out. Increases in $\theta_{\mathrm{j}}$ represent Hicks-neutral technological progress in industry j. It can be shown ${ }^{4}$ that the resulting revenue function has the form $r(\theta \mathbf{p}, \mathbf{v})$, where $\theta=\operatorname{diag}\left(\theta_{1}\right.$, $\left.\theta_{2}, \ldots, \theta_{\mathrm{N}}\right\}$. This formulation implies that industry specific neutral technological change can be modeled in the same way as industry specific price increases, and the net output vector is again given by the gradient of the revenue function with respect to $p$. Differentiation of $r(\theta p, v)$ with respect to $\theta$ establishes that the elasticity of an industry's output with respect to technical progress in that industry is equal to one plus the own-price output elasticity 5 .

It is straightforward to show using revealed profit maximization logic that there is a positive correlation between technical progress and output, holding factor supplies fixed; this

\footnotetext{
${ }^{3}$ If there are more goods than factors, the GDP-maximizing output vector is not unique, and the gradient $r_{p}(\mathbf{p}, \mathbf{v})$ needs to be re-interpreted as a set of sub-gradient vectors.

See, for instance, Dixit and Norman (1980), pg. 137-139.

${ }^{5}$ A discussion of these issues in terms of the primal cost functions can be found in Jones (1965).
} 
follows also from the convexity of $r(\mathbf{p}, \mathbf{v})$ in $\mathbf{p}$. It is not generally true, however, that if we look across countries that technical advantage in an industry will be associated with greater relative output in that industry. This is because the Rybczynski effects of differences in relative factor endowments may affect outputs in the opposite direction. It is difficult to obtain useful theoretical results on the relative importance of factor supplies and technology differences in determining specialization, especially in the general case of large numbers of goods and factors. This fact is a partial motivation for this paper: only estimation tied closely to theory can shed light on the empirical importance of the different determinants of specialization.

\section{An Empirical Model}

To make further progress on a model which can be used as a basis for empirical work requires that we assume a functional form for $r(\theta p, v)$. Following Woodland (1982) and Kohli (1991), suppose that we approximate the true revenue function with a translog function, in particular,

$$
\begin{aligned}
\ln r(\theta p, v)=a_{o o} & +\sum_{j} a_{0 j} \ln \theta_{j} p_{j}+1 / 2 \cdot \sum_{j} \sum_{k} a_{j k} \ln \theta_{j} p_{j} \ln \theta_{k} p_{k} \\
& +\sum_{\mathrm{I}} b_{0 i} \ln v_{i}+1 / 2 \cdot \sum_{l} \sum_{m} b_{i m} \ln v_{i} \ln v_{m} \\
& +1 / 2 \cdot \sum_{j} \sum_{l} c_{j i} \ln \theta_{j} p_{j} \ln v_{i}
\end{aligned}
$$

where the summations over $\mathrm{j}$ and $\mathrm{k}$ run from $\mathrm{l}$ to $\mathrm{N}$ and the summations over $\mathrm{I}$ and $\mathrm{m}$ run from $\mathrm{l}$ to M. Symmetry of cross effects requires that $a_{j k}=a_{k j}$ and $b_{i m}=b_{m i}$ for all $j, k, I$, and $m$. Linear homogeneity in $\mathbf{v}$ and in $\mathbf{p}$ requires

$$
\sum_{j} a_{0 j}=1 \quad \sum_{l} b_{0 i}=1 \quad \sum_{j} a_{k j}=0 \quad \sum_{l} b_{i m}=0 \quad \sum_{l} c_{j i}=0
$$


Differentiating $\ln r(\theta p, v)$ with respect to each $\ln \mathrm{p}_{\mathrm{j}}$ and imposing the homogeneity restrictions $\sum_{\mathrm{j}}$ $a_{k j}=0$ and $\sum_{1} c_{j i}=0$ gives the share of product $j$ in GDP, $S_{j}=p_{j} \cdot x_{j} / Y$ as a function of technology parameters, prices and factor supplies:

$$
S_{j}=a_{0 j}+\sum_{k=2}^{N} a_{k j} \ln \frac{p_{k}}{p_{1}}+\sum_{k=2}^{N} a_{k j} \ln \frac{\theta_{k}}{\theta_{1}}+\sum_{i=2}^{M} c_{i j} \ln \frac{v_{i}}{v_{1}}
$$

Now suppose that each country faces the same prices in each period (that is, free trade), but that countries differ in their factor endowments and technologies. Choosing a country and a year as a reference point and using $c$ and $t$ subscripts to denote countries and years, we have

$$
S_{j c t}=a_{0 j}+\sum_{k=2}^{N} a_{k j} \ln \frac{p_{k t}}{p_{1 t}}+\sum_{k=2}^{N} a_{k j} \ln \frac{\theta_{k c t}}{\theta_{1 c t}}+\sum_{i=2}^{M} c_{i j} \ln \frac{v_{i c t}}{v_{1 c t}}
$$

Defining $d_{j t}=\sum_{k t} a_{k j} \ln \left(p_{k l} / p_{t l}\right)$, equation (1) simplifies to

$$
S_{j c t}=a_{0 j}+d_{j t}+\sum_{k=2}^{N} a_{k j} \ln \frac{\theta_{k c t}}{\theta_{1 c t}}+\sum_{i=2}^{M} c_{i j} \ln \frac{v_{i c t}}{v_{\mathrm{lct}}}
$$

With data on output shares, technology, and factor endowments, this equation can be estimated over a panel of countries and years for each industry $\mathrm{j}$. If there are neutral technology differences across sectors for a particular country, so that $\theta_{\mathrm{kct}}=\theta_{\mathrm{c} \text {, }}$ then the first summation in (2) disappears and output shares depend only on relative factor supplies. In such a case cross-country technology differences determine the level, but not the composition, of GDP. This is the assumption about technology made by Trefler (1995). 
A complication arises when we consider that many goods are non-traded. Denoting the full vector of goods prices as $\mathrm{P}$, partition $\mathrm{P}$ into

$$
P=(\mathbf{p ~ q})
$$

where $\mathbf{p}$ is an $\mathrm{N}_{1} \times 1$ vector of traded goods prices and $\mathbf{q}$ is an $\mathrm{N}_{2} \times 1$ vector of non-traded goods prices. Free trade still allows us to assume $p_{c t}=p_{t}$ for all countries $c$, but generally $q_{c t} \neq q_{b t}$ for two countries $b$ and $c$. This implies that equation (2) becomes

$$
S_{j c t}=a_{0 j}+d_{j t}+\sum_{k=2}^{N} a_{k j} \ln \frac{\theta_{k c t}}{\theta_{1 c t}}+\sum_{k=N_{\mathrm{t}}+1}^{N} a_{k j} \ln \frac{q_{k c t}}{p_{1 t}}+\sum_{i=2}^{M}
$$

Equation (3) differs from (2) by the presence of the summation involving relative non-traded goods prices; in (3), the term $\mathrm{d}_{\mathrm{jt}}$ absorbs only the traded goods prices:

$$
d_{j t}=\sum_{k=2}^{N_{1}} a_{k j} \ln \frac{p_{k t}}{p_{1 t}}
$$

Note also that the first summation in (3) includes both traded and non-traded goods relative technology parameters.

With data on non-traded goods prices and technology across countries, equation (3) can be estimated in the same way as equation (2). However, data on the prices of non-traded goods are not generally available. In addition, measurement of the output and productivity of the government and service sectors (to name the two largest non-traded sectors) is notoriously difficult even within a single country, and international comparisons are yet more difficult. Accordingly, these variables are for practical purposes unobservable. An approach which recognizes both the importance and the unobservability of the non-traded goods effects is to treat 
them as random with some estimable probability distribution. Define the sum of the non-traded goods price and non-traded technology terms in (3) as

$$
\epsilon_{j c r}=\sum_{k=N_{1}+1}^{N} a_{k j} \ln \frac{q_{k c t}}{p_{1 t}}+\sum_{k=N_{1}+1}^{N} a_{k j} \ln \frac{\theta_{k c t}}{\theta_{1 t}}
$$

A simple and flexible model for the stochastic process governing $\epsilon_{\mathrm{jct}}$ is

$$
\epsilon_{\mathrm{jct}}=\eta_{\mathrm{jc}}+\mu_{\mathrm{jt}}+\mathrm{e}_{\mathrm{jct}} \quad, \quad \mathrm{e}_{\mathrm{jct}} \sim \mathrm{N}\left(0, \sigma_{\mathrm{j}}^{2}\right)
$$

That is, treat the sum of the non-traded goods effects as a random variable with country fixed effects $\eta_{j c}$, time fixed effects $\mu_{j l}$, and a random component $e_{j c l}$ with constant variance $\sigma_{j}^{2}$. Rewriting (3) using the definition in (4) gives the equation to be estimated:

$$
S_{j c t}=\eta_{j c}+\delta_{j t}+\sum_{k=1}^{N_{1}} a_{k j} \ln \theta_{k c t}+\sum_{i=2}^{M} c_{i j} \ln \frac{v_{i c t}}{v_{l c t}}+e_{j c t}
$$

where $\delta_{j t}=\mu_{j t}+d_{j t}$ is the combined time-specific effect of all goods prices and non-traded goods technology parameters. Note that since not all technology parameters are observed, there is no homogeneity restriction governing the sum of the observable technology effects. The only sign restriction on equation (5) that can be established by theory is that the own-TFP effect, $a_{i j}$, is positive: holding factor supplies and other levels of TFP constant, an increase in a sector's TFP should lead to an increase in the share of GDP accounted for by that sector. Theory also requires that the cross-TFP effects are symmetric, $a_{k j}=a_{j k}$ for all sectors $j$ and $k, k \neq j$. 


\section{Data, Measurement, and Econometrics}

Empirical implementation of the model described in the previous section requires data on output shares, technology, and factor supplies. I first briefly discuss the theoretical issues involved in measuring industry technology, and then discuss data sources. Lastly, I discuss appropriate econometric techniques for dealing with the cross-equation restrictions, partial adjustment, and potential measurement error biases.

\subsection{Total Factor Productivity Comparisons}

The Hicks-neutral technology parameters $\theta_{\text {kct }}$ are measured using an index of total factor productivity (TFP). TFP calculations at the industry level require real, internationally comparable data on industry outputs and inputs of primary factors and intermediate goods. For practical purposes, information on inputs other than capital and labor is not available in internationally comparable form, so I calculate value added TFP indexes. Value added TFP calculations are strictly appropriate only when a well-defined value added function exists, which requires separability between capital and labor and other inputs. Consequently, the TFP calculations reported in this paper should be treated as approximations to true $\mathrm{TFP}^{6}$.

TFP comparisons are a classic index number problem and therefore TFP indexes have no unique optimal form, but an index proposed by Caves, Christensen, and Diewert (1982) is appropriate for this application. Suppose that value added $\mathrm{y}$ is a function of capital $\mathrm{k}$ and labor $\mathrm{l}$.

\footnotetext{
${ }^{6}$ On the theory of value added functions, see Diewert (1978). Jorgenson and Kuroda (1990) compute USJapanese TFP comparisons using appropriately (and laboriously) constructed data on materials and intermediate goods, and their calculations of TFP levels are not too different from the value-added TFP comparisons in Harrigan (1994b).
} 
Suppressing the industry and time subscripts for readability, the index for any two countries $b$ and $\mathrm{c}$ is given by

$$
T F P_{b c}=\frac{y_{b}}{y_{c}}\left(\frac{\bar{l}}{l_{b}}\right)^{\sigma_{b}}\left(\frac{\bar{k}}{k_{b}}\right)^{1-\sigma_{b}}\left(\frac{l_{c}}{\bar{l}}\right)^{\sigma_{c}}\left(\frac{k_{c}}{\bar{k}}\right)^{1-\sigma_{c}}
$$

where $I$ and $\mathrm{k}$ are geometric averages over all the observations in the sample and $\sigma_{c}=\left(s_{c}+\bar{s}\right) / 2$, where $s_{c}$ is labor's share in total cost in country c. To interpret (6), notice that if the value added function is Cobb-Douglas, then the labor shares are constant and (6) reduces to the CobbDouglas index:

$$
T F P_{b c}=\frac{y_{b}}{y_{c}}\left(\frac{l_{c}}{l_{b}}\right)^{s}\left(\frac{k_{c}}{k_{b}}\right)^{1-s}
$$

The index (6) is superlative, meaning that it is exact for the flexible translog functional form. Furthermore, (6) is transitive:

$$
\operatorname{TFP}_{\mathrm{ac}}=\mathrm{TFP}_{\mathrm{ab}} \cdot \mathrm{TFP}_{\mathrm{bc}}
$$

which makes the choice of base country and year inconsequential. For more on the theory of TFP comparisons and its application to cross-country comparisons of industry level data, see Harrigan (1994b).

Computation of indexes like (6) requires real, internationally comparable data on value added, labor input, and capital input. The OECD has a database called the "International Sectoral Data Base" or ISDB which contains just such data classified according to the nine two-digit categories of the ISIC. The ISDB data reports capital stocks in addition to employment and value added for eleven OECD countries (the United States, Canada, Japan, Sweden, Norway and six 
European Union states: Britain, France, Germany, Italy, Belgium, and Denmark) for the years 1970 to 1990 . I adjust the ISDB data on employment by average hours worked per week in manufacturing to get a measure of labor input. A problem with the ISDB data is that the share of labor in value added is very noisy, and frequently exceeds one. To control for this, I use a smoothing procedure based on the fact that, when the value added function is given by a translog and standard market clearing assumptions hold, labor's share in value added in industry $\mathrm{j}$ in year $\mathrm{t}$ in country $\mathrm{c}$ is

$$
s_{\mathrm{cjt}}=\delta_{\mathrm{Icj}}+\delta_{2 \mathrm{j}} \ln \left(\mathrm{k}_{\mathrm{cj}} \Lambda_{\mathrm{cjt}}\right)
$$

If observed labor shares deviate from this equation by an i.i.d. measurement error term, then its' parameters can be estimated by regressing labor shares on country fixed effects and industry capital-labor ratios, with a separate regression for each industry. I use the fitted values from these regressions as the labor cost shares in constructing the TFP indexes given by equation (6).

The ISDB uses overall GDP purchasing power parity exchange rates to convert industry outputs into internationally comparable units. This implicitly assumes that relative prices are the same in different countries; to the extent that they are not, output comparisons will be distorted. For example, suppose that country A and country B have identical technology but that the price of machinery relative to chemicals is higher in country $\mathrm{A}$ than in country $\mathrm{B}$, perhaps due to differences in the quality mix in the two countries. Deflating industry outputs by the overall GDP price level will lead to the erroneous conclusion that country A has superior technology in chemicals and inferior technology in machinery in comparison to country B. If the structure of relative prices is fairly constant within a country over time, then this measurement procedure 
induces a constant country-specific multiplicative measurement error into the TFP comparisons ${ }^{7}$. The implications of this for estimation are addressed in section 4.3 below. For further details on the ISDB data and the computation of TFP, see the appendix to this paper.

\subsection{Factor Supplies}

I consider three types of factor supplies: land, labor, and capital. Data on aggregate capital stocks come from version 5.6 of the Penn-World Tables, available by anonymous ftp from nber.harvard.edu. The Penn-World Table classifies capital stocks into producer durables, nonresidential and other construction, and residential construction. I use only the first two capital stock measures, since residential construction is most appropriately regarded as a component of consumption for the purposes of this paper. Information on arable land comes from the World Resources database on diskette ${ }^{8}$.

I classify labor endowments according to the educational levels of workers. The data on educational attainment comes from Barro and Lee (1993), whose data are also available by anonymous ftp from nber.harvard.edu. Barro and Lee construct estimates of the level of educational attainment in the population, and I use their data to classify workers into three categories:

1. Highly-educated workers, who have at least some post-secondary education .

\footnotetext{
${ }^{7}$ It is possible to compare the structure of relative prices across countries by examining the source documents for the construction of the OECD's purchasing power parities. Harrigan (1994b) does this, and shows that relative prices vary much less over time within a country than across countries at a point in time. This supports the view that a constant multiplicative factor will capture most of the error in the TFP calculations in this paper.

"It would be desirable to use data on other natural resources. Arable land is the only natural resource variable that I use in the empirical work because of gaps in the coverage of other natural resource stocks.
} 
2. Medium-educated workers, who have at least some secondary education but no higher education, and

3. Low-educated workers, who have no secondary education (almost all of this category consists of workers with at least some primary education).

This education based classification is probably preferable to the occupational based classification used by (among others) Leamer (1984) and Harrigan (1995) for two reasons. The first is that educational levels are more likely to be exogenous with respect to output shares than occupational classifications, since growth in some industries might induce workers to shift their occupations. The second is that education is probably more closely related to skill than is occupation.

\subsection{Estimation: Cross-equation restrictions, partial adjustment, and measurement error}

As noted at the end of section 3, the translog functional form implies that there are linear cross-equation symmetry restrictions among the system of output share equations (5) for a group of industries. These restrictions are imposed by using a restricted SURE estimator, which is an asymptotically efficient GLS estimator if the restrictions are valid".

The neoclassical model assumes free movement of factors among sectors. If re-allocation of factors occurs with a lag in response to changes in technology, prices, and aggregate factor supplies, then equation (5) will hold only after adjustment has taken place. With slow adjustment to equilibrium, output shares in the short run can be modeled as

\footnotetext{
${ }^{9}$ See Greene (1993), Chapter 17, for a clear exposition of estimating a system of translog share equations. As Greene notes, if data on all sectors is available, then the system is singular and maximum likelihood is the recommended estimator. Since I do not estimate shares for all sectors, restricted GLS is appropriate.
} 


$$
S_{j c t}=\lambda_{j} S_{j c, t-1}+\eta_{j c}+\delta_{j t}+\sum_{k=1}^{N_{1}} a_{k j} \ln \theta_{k c t}+\sum_{i=2}^{M} c_{i j} \ln \frac{v_{i c t}}{v_{l c t}}
$$

where $\lambda_{j}$ is the speed of adjustment, and the long-run effect of a change in $\theta_{k}$ is given by $a_{k j} /(1$ $\left.\lambda_{j}\right)$. Because symmetry requires $a_{k j}=a_{j k}$, it also requires $\lambda_{j}=\lambda_{k}$. Therefore, the coefficient on the lagged output share will be constrained to be the same for each equation when (7) is estimated. As noted in Hsiao (1986, section 4.2), for short panels the OLS estimator of $\lambda_{\mathrm{j}}$ is biased downward and inconsistent. A consistent estimator uses a two period lag of the dependent variable to instrument for the lagged dependent variable, and this is the procedure that is followed in the results reported below.

A problem with estimation of (5) and (7) is the severe measurement error in all of the right hand side variables. It is likely that there are two types of measurement error that infect observed factor supplies and relative TFP. The first is systematic, and is a result of differences in measurement procedures and factor quality across countries and over time. For example, differences in soil quality are country specific and will infect the measurement of arable land, while exchange rate fluctuations and imperfections in the calculation of purchasing power parity exchange rates are both country and time specific and will affect the comparisons of capital stocks and TFP. The second type of error is classical random measurement error which arises due to imperfect application of any given measurement technique. A model of this dual type of measurement error for explanatory variable $\mathrm{I}$ in country $\mathrm{c}$ at time $\mathrm{t}$ is 


$$
\mathrm{z}_{\mathrm{ict}}=\mathrm{a}_{\mathrm{c}} \cdot \mathrm{b}_{\mathrm{t}} \cdot \mathrm{z}^{*}{ }_{\mathrm{ict}} \cdot \exp \left\{\mathrm{e}_{\mathrm{ict}}\right\}
$$

where $\mathbf{z}_{\text {ict }}=$ observed value of variable $I$ in country $\mathrm{c}$ at time $\mathrm{t}$,

$\mathbf{z}^{*}{ }_{\text {ict }}=$ actual value of variable $I$ in country $\mathrm{c}$ at time $\mathrm{t}$,

$a_{c}, b_{t}=$ country-specific and time-specific systematic measurement errors

$e_{i c t}=$ normally distributed classical measurement error with mean 0 and variance $\sigma^{2}{ }_{i}$

Taking logarithms of both sides of (8a) gives

$$
\ln z_{i c t}=\alpha_{c}+\beta_{t}+\ln z^{*}{ }_{i c t}+e_{i c t}
$$

where $\alpha_{c} \equiv \ln a_{c}$ and $\beta_{\mathrm{c}} \equiv \ln b_{\mathrm{t}}$. Substituting (8b) into (5) or (7) and collecting terms, it becomes apparent that the systematic measurement errors $\alpha_{c}$ and $\beta_{t}$ will be absorbed into the country and time fixed effects $\eta_{j c}$ and $\delta_{j t}$, leaving only the classical measurement errors $e_{i c t}$ on the right hand side. Of course, the ideal solution to classical measurement error is to use an instrumental variables estimator. It seems reasonable to assume that true technology levels are correlated across countries while technology measurement errors are uncorrelated across countries, which means that one country's TFP level is a valid instrument for another country's TFP level. Consequently, I instrument industry $\mathrm{k}$ TFP in country $\mathrm{c}$ in year $\mathrm{t}$ by the average of all other country's industry $k$ TFP in year $t$. In other words, the instrument for $\theta_{k c t}$ is

$$
\frac{1}{C-1} \sum_{d \neq c}^{C} \theta_{k d t}, \quad k=1, \ldots, N
$$

where $\mathrm{C}$ is the number of countries in the sample.

Unfortunately, there are no good instruments available for factor supplies. As shown by Klepper and Leamer (1984), the degree of inconsistency caused by classical measurement error in multiple right hand side variables can be bounded, and the tightness of the bounds is a function 
of the $R^{2}$ of the regression equation. The $R^{2} s$ of the regressions of the share equations (5) and (7) vary between 0.92 and 0.98 , so that the degree of inconsistency due to classical measurement error in the factor endowment variables is very small. Consequently, I do not pursue the calculation of the measurement error bounds as outlined by Klepper and Leamer.

\subsection{Data Summary}

Table 1 summarizes the coverage and organization of the data. The sample includes all of the largest developed countries as well as a number of smaller European economies and covers the period 1970 to 1988 , with a number of countries having data up to 1990 . Table 2 gives an indication of how the ten countries differ in what they produce. The first column of Table 2 gives the share of manufacturing value added in each country's total GDP in 1970 and 1988. Each country saw a drop in manufacturing's share of GDP over the period. The other columns of the table give the share of each industry in total manufacturing value added. By far the largest sector is Machinery, which accounted for over a third of total manufacturing value added in most countries. The sector which saw the largest decline in its share of manufacturing was Textiles and Apparel. After Machinery, the next two largest sectors were generally Food and Chemicals, with Paper an important sector in the heavily forested countries of Canada and Sweden. The variability in these output shares across countries and over time is what the empirical model in the next section is designed to explain.

The explanatory variables of the model are summarized in Tables 3 and 4 . Table 3 shows the levels of factor endowments at the end of the sample as well as the average annual growth rates of the endowments over the sample. The type of systematic measurement error discussed in the previous section is evident in this table, particularly in the education variables. For example, 
Germany has a very small number of college-educated workers relative to the United States but far more low-educated workers, which may have more to do with differences in the educational systems in the two countries than with differences in the skill levels of the two workforces. Most countries saw small declines in arable land and somewhat larger declines in low-educated workers over the period, while the other types of labor and both types of capital generally grew.

The total factor productivity data are summarized in Table 4. Not surprisingly, there is generally strong growth over time in TFP, although there are some exceptions, particularly in the Food sector. The US was the leader in TFP in most sectors both at the beginning and at the end of the sample, an observation which accords with Dollar and Wolff (1993) and Harrigan (1994a, 1994b) among other researchers. Careful scrutiny of this table uncovers a number of apparent anomalies (for example, was Japanese TFP in Food really 23\% higher in 1970 than US TFP in 1988?), so these comparisons should be taken as fairly noisy indicators of true technology differences.

\section{Empirical Results}

Equations (5) and (7) are estimated as a system of restricted seemingly unrelated regressions, and the results are reported in Tables 5 and 6 respectively, with hypothesis tests reported in Table 8. Standardized coefficients for equations (5) and (7) are reported in Table 7. The estimates in Table 5 are computed subject to the symmetry and homogeneity constraints, while the Table 6 results have the additional restriction that the coefficient on the lagged dependent variable is the same in each equation. For each sector, the dependent variable is the percentage share of that sector's output in GDP, and the explanatory variables are the log of TFP in all sectors and the log of six different types of factor endowments. Since the dependent 
variable is a percentage, the estimated parameters have the interpretation of a semi-elasticity. For example, a parameter estimate of 2.0 means that a $10 \%$ increase in the independent variable will raise the output share by 0.20 percentage points. Country and time fixed effects are included in each equation but are not reported for space reasons; they are reported in an appendix which is available upon request.

For each estimated equation, the TFP variable corresponding to the industry output share being explained is highlighted to make the table easier to read. According to the theory, this parameter is the own-price output effect and should be non-negative. In most cases, this ownTFP parameter is estimated to be positive and statistically significant: in Table 5, five of the seven sectors have positive own-TFP effects, while in Table 6 all seven sectors have positive own-TFP effects ${ }^{10}$. The largest positive effect is in the Machinery sector: a $10 \%$ improvement in relative TFP raises Machinery's share of GDP by 0.2 or 0.3 percentage points. The Chemicals sector has an own-TFP effect of over 1, while the Apparel, Glass, and Metals sectors have relatively small own-TFP effects of less than 1 . The Paper sector has a small positive own-TFP effect which is significant only in Table 6, while the Food category has an own-TFP effect ambiguous sign: it is negative in Table 5 and positive in Table 6. This failure of the theory for the Food sector is in itself an interesting result which hints that the output of this sector depends more on factors such as government policy than on purely economic considerations. Students of agricultural policy in the world economy may find this particularly unsurprising.

\footnotetext{
${ }^{10}$ The covariance matrix of the restricted GLS estimator is asymptotically normal. Here and in what follows, my cutoff for "statistical significance" is $|t| \geq 1.64$, which is the $10 \%$ cutoff point for the standard normal.
} 
As the theory suggests, the cross-TFP effects are a mix of positive and negative, although the signs and statistical significance are somewhat fragile across the two tables. Of the 21 crossTFP effects, only 3 are statistically significant and of the same sign in both tables: negative Machinery-Chemicals, Glass-Foods, and Apparel-Chemicals cross-effects. The strongest crossTFP effect is between TFP in Chemicals and Machinery: TFP growth in one of these sectors evidently draws resources out of the other sector. These are also the two sectors with the largest own-TFP effects.

Turning to the effect of factor supplies on GDP shares, I first focus on Table 5. The two types of capital tend to have different effects. Abundance in producer durables is generally associated with larger output in most sectors, while greater supplies of non-residential construction are associated with lower output shares: this pattern holds in the Apparel, Chemicals, Glass and Machinery sectors, and in addition producer durables have a positive effect in the Food sector. Abundance in highly educated workers has a uniformly negative or negligible effect on the output shares of all industries, medium-educated workers have a positive or negligible effect on the output shares of all but the Chemicals sector, and low-educated workers have large effects only in the Chemicals (negative) and Machinery (positive) sectors. The effects of land are mixed, with a surprising negative effect in the Food sector, although it should be recognized that this sector is the output of processed food and beverages and not agricultural production per se.

To summarize, the most reliable inferences across sectors about the effects of factor abundance on output shares are 1) Producer durables and medium-educated workers are associated with larger shares, and 2) Non-residential Construction and High-educated Workers 
are associated with lower shares. These findings suggest a simple story: the service sector is intensive in non-residential construction (office buildings and retail stores) and college-educated workers (managers, professionals, educators), so that abundance in these factors draws other resources out of manufacturing and into the service sector. By contrast, the manufacturing sectors are intensive in producer durables and medium-educated workers, so that abundance in these factors draws resources out of services and into manufacturing sectors. While plausible, confirmation of this explanation would require data on direct factor shares which are not easily available in internationally comparable form.

The results about factor abundance are roughly consistent with Harrigan (1995). That paper used a somewhat different model, data set, and set of factor endowment variables, and found that capital abundance was associated with larger output in most manufacturing industries and skilled labor abundance was associated with lower output in most industries. The results are also roughly consistent with Leamer's (1984) findings about the net export effects of factor abundance.

Turning to Table 6, it is much more difficult to sign the effects of factor supplies on output shares. For example, non-residential construction has a significant effect in only one sector, and medium-educated workers have no significant effects. Evidently, the slow adjustment (the estimated coefficient on the lagged output share is 0.699 ) of output shares to the movement of relative factor supplies obscures the equilibrium relationship that was apparent when adjustment was assumed to be immediate, as it is in Table 5.

To help understand the size of the effects reported in Tables 5 and 6, Table 7 reports standardized coefficients, which are transformations of the regression coefficients into units of 
sample standard deviations ${ }^{11}$. For example, a standardized coefficient of 1.3 means that a one standard deviation increase in the explanatory variable will increase the dependent variable by 1.3 standard deviations. The standardized coefficients corresponding to Table 5 are reported in columns A of Table 7. Columns B of Table 7 report long-run standardized coefficients, where each slope is first divided by $1-\lambda$ to convert it into a long-run effect. Boxes are shaded if the corresponding slope in Table 5 or 6 is significantly different from zero at the $10 \%$ level. The estimated long-run own-TFP effects in columns B are invariably larger than the effects in column A; generally, a one-standard deviation increase in own-TFP has a moderate to large effect on the GDP share. The cross-TFP effects are almost all negligible except for the Machinery-Chemicals effect. Where statistically significant, the factor endowment effects are generally large, with many standardized coefficients greater than one in absolute value and most greater than 0.5 .

Table 8 reports some hypothesis tests relating to the results in Tables 5 and 6 . The symmetry restrictions (Hypotheses A1, B1, and B2) are rejected, while the homogeneity of the factor supply effects is generally not rejected (Hypotheses A3 and B3). The TFP and factor supply effects are jointly significant for each equation in Table 5, but the picture is less clear for Table 6: the TFP variables are not significant in the Food sector, and factor supplies do not have significant effects in the Glass and Metals sectors.

Because the results of Tables 5 and 6 are computed using a fixed effects estimator, crosscountry variation in TFP and factor supplies is not used in estimation; in other words, only timeseries variation within countries is used to identify the parameters. Mechanically, the estimator

\footnotetext{
"Standardized coefficients are often known as "beta" coefficients. Standardized coefficients are formed by multiplying the regression slope by the standard deviation of the explanatory variable and dividing by the standard deviation of the dependent variable.
} 
proceeds in two steps: first, country and time means are subtracted by regressing each variable on country and time period dummies; second, the restricted SURE estimator is applied to the residuals from these regressions. To see how the estimated model does in predicting crosscountry variation in GDP shares, I constructed predicted values using the estimated coefficients multiplied by variables with only time means removed. These predicted values are compared to the actual GDP shares in Table 9. Not surprisingly given the large magnitude of cross-country variation in GDP shares (see Table 2), the results are mixed: for equation (5) the correlation between predicted and actual is positive in five of seven sectors, while Chemicals and Metals have negative correlations. Equation (7) does much better, with high positive correlations in all sectors; this is surely due to the lagged dependent variable in Equation (7). Better cross-country measurement of TFP and factor supplies, as well as modeling of cross-country differences in the size of the non-traded goods sector, would probably lead to a smaller amount of unexplained cross-country variation in GDP shares.

\section{Conclusion}

This paper is the first to estimate a model where technology and factor supply differences jointly determine international specialization. This methodology is consistent with but less restrictive than the even model of Leamer (1984) and Harrigan (1995) and also encompasses the modified factor price equalization approach of Trefler $(1993,1995)$. The estimated effect of technology differences is generally large and in accord with the theory, suggesting that Ricardian effects are an important source of comparative advantage. Factor endowment differences are also found to have large effects on output shares, and the pattern of estimated effects is informative, 
although the factor supply effects are elusive when a lagged dependent variable is included in the specification.

While the paper does not explicitly address trade, the implications for trade are immediate: to the extent that countries have similar tastes, the inferences about the determinants of a country's production pattern found here will translate into inferences about the country's trade pattern ${ }^{12}$. The results of this paper do not necessarily conflict with Trefler's (1995) result that the factor content of a country's net trade is approximately equal to it's effective excess factor supplies. Trefler showed that for aggregate calculations about the factor content of trade it is reasonable to abstract from non-neutral technology differences by assuming that each country's factor requirement matrix ${ }^{13}$ is a scalar multiple of the US matrix. What the current paper shows is that non-neutral technology differences are important for explaining specialization. One difficulty in comparing Trefler's paper to this one is that the effective factor content of trade is not well-defined when there are non-neutral technology differences across sectors: when a country's factor requirements matrix can not be expressed as scalar multiple of the US matrix the measured factor content of trade will depend on which factor requirements matrix is used in the calculation.

This paper has been primarily concerned with testing the neoclassical theory of international specialization, but it has implications for empirical modelers and policy makers as well as theorists. For empirical modelers using the neoclassical framework, the message is that

\footnotetext{
${ }^{12}$ Similarity in tastes may explain why the results of this paper are consistent with Leamer's (1984) estimates of the effects of factor endowments on net exports, as noted in the previous section.

${ }^{13}$ That is, the A matrix in the usual statement of the factor market clearing conditions, $A \mathbf{x}=\mathbf{v}$.
} 
some of the defects of the Heckscher-Ohlin model can be remedied by consideration of Hicksneutral technology differences. For policy makers, the message is that both factor supply and technology differences have important impacts on a country's pattern of specialization in the global economy, and that these factors must be considered jointly when formulating policies intended to effect the structure of production and trade.

A final contribution of the paper is that it has demonstrated that the dual approach to general equilibrium theory can greatly simplify cross-country empirical analysis in trade models, especially when panel data is available. The dual approach has been used extensively in time series analysis of trade models, especially by Kohli (1991), but has not been applied to a panel of countries before. 


\section{References}

Ark, Bart van, and Dirk Pilat, 1993, "Productivity Levels in Germany, Japan, and the United States: Differences and Causes", Brookings Papers: Microeconomics 2, 1993, 1-69.

Barro, Robert J., and Jong-Wha Lee, 1993, "International Comparisons of Educational Attainment", NBER Working Paper \#4349, April.

Bowen, Harry P., Leamer, Edward E., and Leo Sveikauskas, 1987, "Multicountry, Multifactor Tests of the Factor Abundance Theory", American Economic Review, (December), 77: 791-809.

Brecher, R. and E. Choudhri, 1993, "Some empirical support for the Heckscher-Ohlin model of production", Canadian Journal of Economics, v. 26 no. 2 (May): 272-285.

Caves, Douglas W., Laurits R. Christensen, and W. Erwin Diewert, 1982, "Multilateral Comparisons of Output, Input, and Productivity using Superlative Index Numbers", The Economic Journal 92 (March): 73-86.

Deardorff, Alan V., 1984, "Testing Trade Theories and Predicting Trade Flows", Chapter 10 in Ronald W. Jones and Peter B. Kenen, eds., Handbook of International Economics, Volume 1, Amsterdam: North Holland.

Diewert, W. Erwin, 1978, "Hicks' Aggregation Theorem and the Existence of a Real Value Added Function", pp. 17-51 in M. Fuss and D. McFadden, Eds., Production Economics: A Dual Approach to Theory and Applications, vol. 2, Amsterdam: North Holland. Reprinted as Chapter 15 in Diewert and A. O. Nakamura, Eds., 1993, Essays in Index Number Theory, vol. 1, Amsterdam: North Holland.

Dixit, Avinash, and Victor Norman, 1980, The Theory of International Trade, Cambridge, England: Cambridge University Press.

Dollar, David, and Edward N. Wolff, 1993, Competitiveness, Convergence, and International Specialization, Cambridge, MA: MIT Press.

Greene, William, 1993, Econometric Analysis, 2nd Edition, New York: Macmillan.

Harrigan, James, 1994a, "Econometric Estimation of Cross-Country Differences in Industry Production Functions", University of Pittsburgh Working Paper.

Harrigan, James, 1994b, "Cross-Country Comparisons of Industry Total Factor Productivity: Theory and Evidence", University of Pittsburgh Working Paper. 
Harrigan, James, 1995, "Factor Endowments and the International Location of Production: Econometric Evidence for the OECD, 1970-1985", Journal of International Economics v. 39: $123-141$.

Helpman, 1984, "Increasing Returns, Imperfect Markets, and Trade Theory", Chapter 7 in Ronald W. Jones and Peter B. Kenen, eds., Handbook of International Economics, Volume I, Amsterdam: North Holland.

Helpman, Elhanan, and Paul Krugman, 1985, Market Structure and Foreign Trade: Increasing Returns, Imperfect Competition, and the International Economy, Cambridge, Mass: MIT Press.

Hunter, Linda, and James Markusen, 1988, "Per Capita Income as a Determinant of Trade", Chapter 4 in Robert Feenstra, Ed., Empirical Methods for International Trade, Cambridge, Mass.: MIT Press.

Jones, R., 1965, "The Structure of Simple General Equilibrium Models", Journal of Political Economy, v. 73: 557-572 (December).

Jorgenson, Dale W., and Masahiro Kuroda, 1990, "Productivity and International Competitiveness in Japan and the United States, 1960-1985", Chapter 1 in Charles R. Hulten, Ed., Productivity Growth in Japan and the United States, Chicago: University of Chicago Press. The paper also appears in Economic Studies Quarterly, v. 43 (December 1992): 313-25.

Klepper, Steven and Edward E. Leamer, 1984, "Consistent Sets of Estimates for Regressions with Errors in All Variables", Econometrica 52, 163-183.

Kohli, Ulrich, 1991, Technology, Duality, and Foreign Trade, Ann Arbor: University of Michigan Press.

Leamer, Edward E., 1984, Sources of International Comparative Advantage: Theory and Evidence, Cambridge, Mass: MIT Press.

Leamer, Edward E. and James Levinsohn, 1995, "International Trade Theory: The Evidence", Chapter 26 in Gene Grossman and Kenneth Rogoff, Eds., The Handbook of International Economics, Volume 3, Amsterdam: North Holland.

Leontief, Wassily, 1954, "Domestic Production and Foreign Trade: The American Capital Position Re-examined", Chapter 30 in Richard E. Caves and Harry G. Johnson, eds., Readings in International Economics, 1968, London: Allen and Unwin. 
Markusen, James, 1986, "Explaining the Volume of Trade: An Eclectic Approach", American Economic Review, v. 76: 1002:1011.

Maskus, Keith E., "A Test of the Heckscher-Ohlin-Vanek Theorem: The Leontief Commonplace", Journal of International Economics, v. 19: 201-212.

Staiger, Robert W., 1988, "A Specification Test of the Heckscher-Ohlin Theory", Journal of International Economics, v. 25: 129-141.

Summers, Robert, and Alan Heston, 1991, "The Penn World Table (Mark V): An Expanded Set of International Comparisons, 1950-1988" Quarterly Journal of Economics, v. 106: 327 368.

Trefler, Daniel, 1993, "International Factor Price Differences: Leontief was Right!", Journal of Political Economy, v. 101 (December): 961-987.

Trefler, Daniel, 1995, "The Case of the Missing Trade and Other Mysteries", American Economic Review, v. 85 (December): 1029-1046.

Woodland, Alan D., 1982, International Trade and Resource Allocation, Amsterdam: North Holland. 


\section{Table 1 - Data set Description}

Years $1970-1990$ (many series stop in 1988)

Countries 10 OECD countries: Canada, the United States, Japan, Belgium, Britain, France, Denmark, West Germany, Italy, and Sweden.

Product Classification System Seven of the nine categories of the two-digit level of the International Standard Industrial Classification (ISIC). The categories, and their three-digit constituent parts, are listed below. ISIC 33, Products of Wood, and ISIC 39, Other Manufacturing, are excluded from the analysis because of missing data.

$\begin{array}{lll}\text { Food } & 311 / 2 & \text { Food manufacturing } \\ & 313 & \text { Beverage industries } \\ \text { Apparel } & 314 & \text { Tobacco manufactures } \\ & 321 & \text { Manufacture of textiles } \\ & 322 & \text { Manufacture of wearing apparel except footwear } \\ & 323 & \text { Manufacture of leather products except footwear and apparel } \\ \text { Paper } & 324 & \text { Manufacture of footwear except rubber or plastic } \\ & 341 & \text { Manufacture of paper and paper products } \\ \text { Chemicals } & 342 & \text { Printing, publishing and allied industries } \\ & 351 & \text { Manufacture of industrial chemicals } \\ & 352 & \text { Manufacture of other chemical products } \\ & 353 & \text { Products of Petroleum refineries } \\ & 354 & \text { Miscellaneous products of petroleum and coal } \\ & 355 & \text { Rubber products } \\ \text { Glass } & 356 & \text { Plastic products not elsewhere classified } \\ & 361 & \text { Pottery, china and earthware } \\ & 362 & \text { Glass and glass products } \\ \text { Metals } & 369 & \text { Other non-metallic mineral products } \\ & 371 & \text { Iron and steel basic industries } \\ & 372 & \text { Non-ferrous metal basic industries } \\ \text { Machinery } & 381 & \text { Fabricated metal products, except machinery and equipment } \\ & 382 & \text { Manufacture of machinery except electrical } \\ & 383 & \text { Electrical machinery, apparatus, appliances and supplies } \\ & 384 & \text { Transport equipment } \\ & 385 & \text { Professional, scientific, measuring and control equipment } \\ & & \end{array}$




\section{Table 1 - Data set Description, continued}

Shares of each industry in GDP

Source: the OECD's International Sectoral Database (ISDB).

Total Factor Productivity

Author's calculation of total factor productivity uses data on real value added, capital stocks, and employment by industry, country, and year from the ISDB. For details see the text and the appendix.

\section{Factor Endowments}

Capital Using version 5.6 of the Penn-World Table (PWT 5.6), capital is classified into two categories: 1) durable goods capital and 2) non-residential construction and other capital. Units: millions of 1985 international dollars. See Heston and Summers (1991) for details.

Labor The economically active population (from PWT 5.6) is classified according to education level: 1) low, workers with at most primary education, 2) medium, workers with at most secondary education, and 3) high, workers with at least some higher education. Units: Thousands of workers. The educational classification for 1970, 1975, 1980, and 1985 comes from Barro and Lee (1993); intervening years are interpolated and years after 1985 are projected using the $1980-85$ trend. See Barro and Lee (1993) for details.

Land Arable land. Units: thousands of hectares. The source is the World Resources Data Base on diskette. 


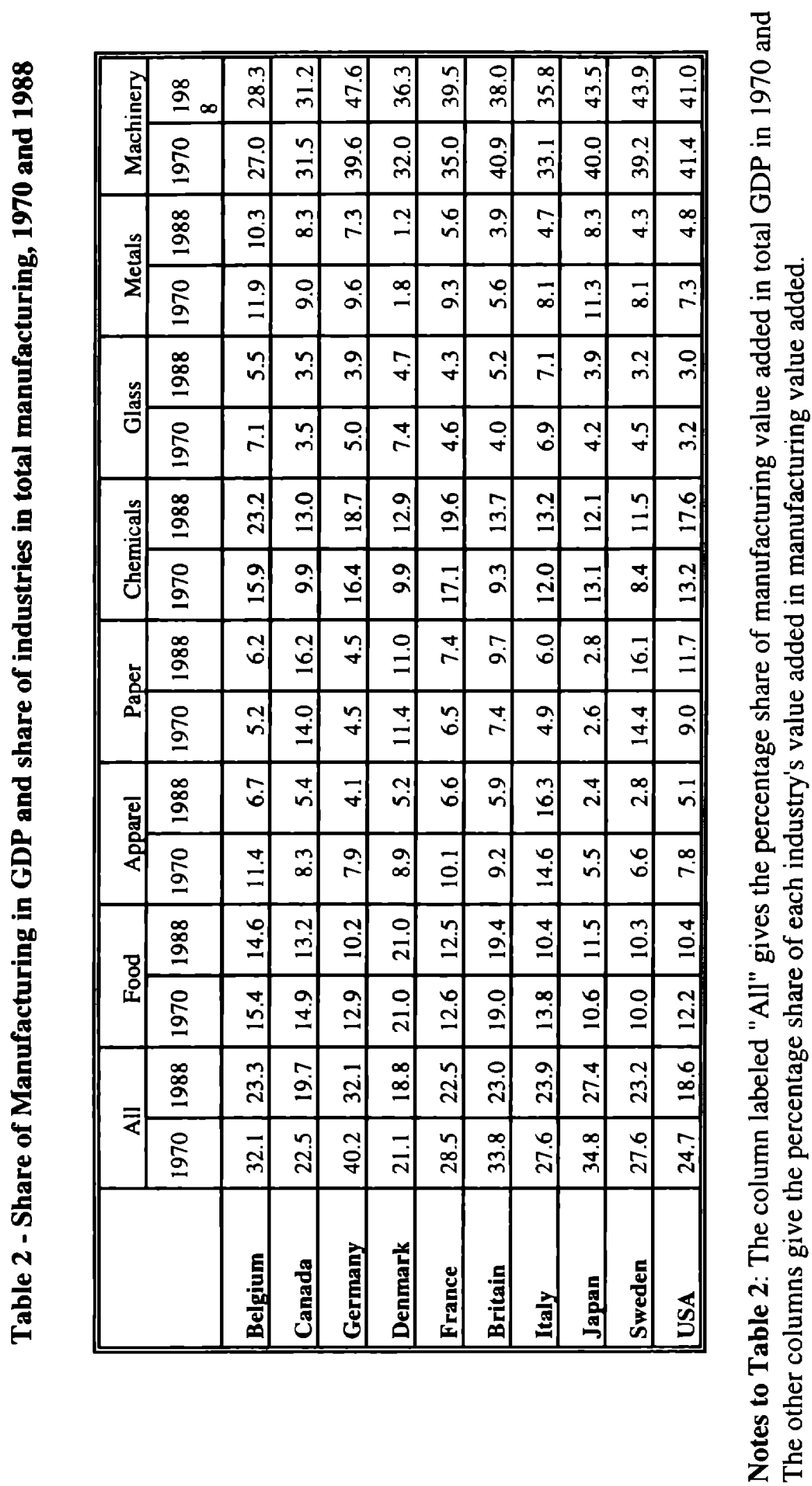




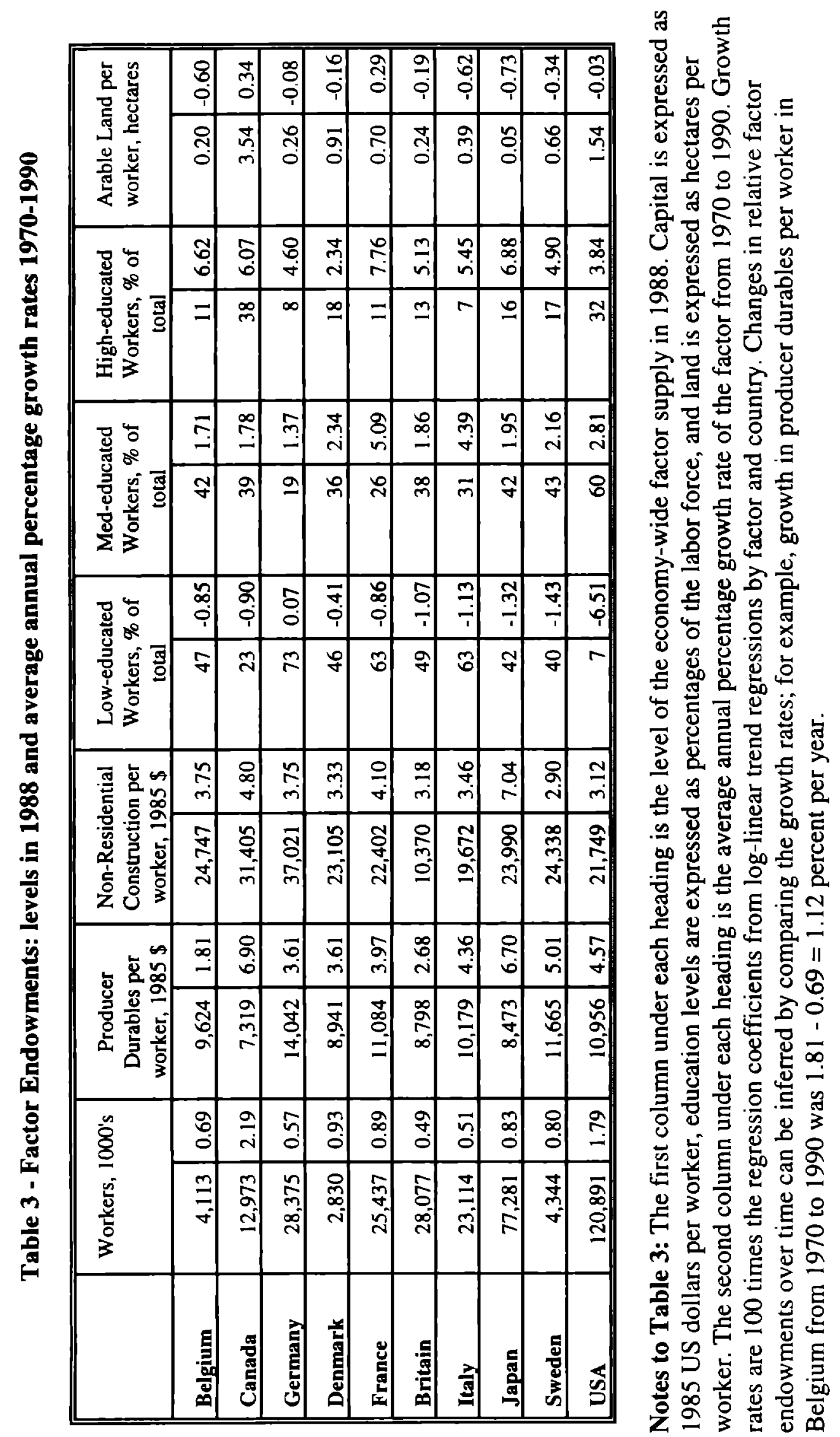




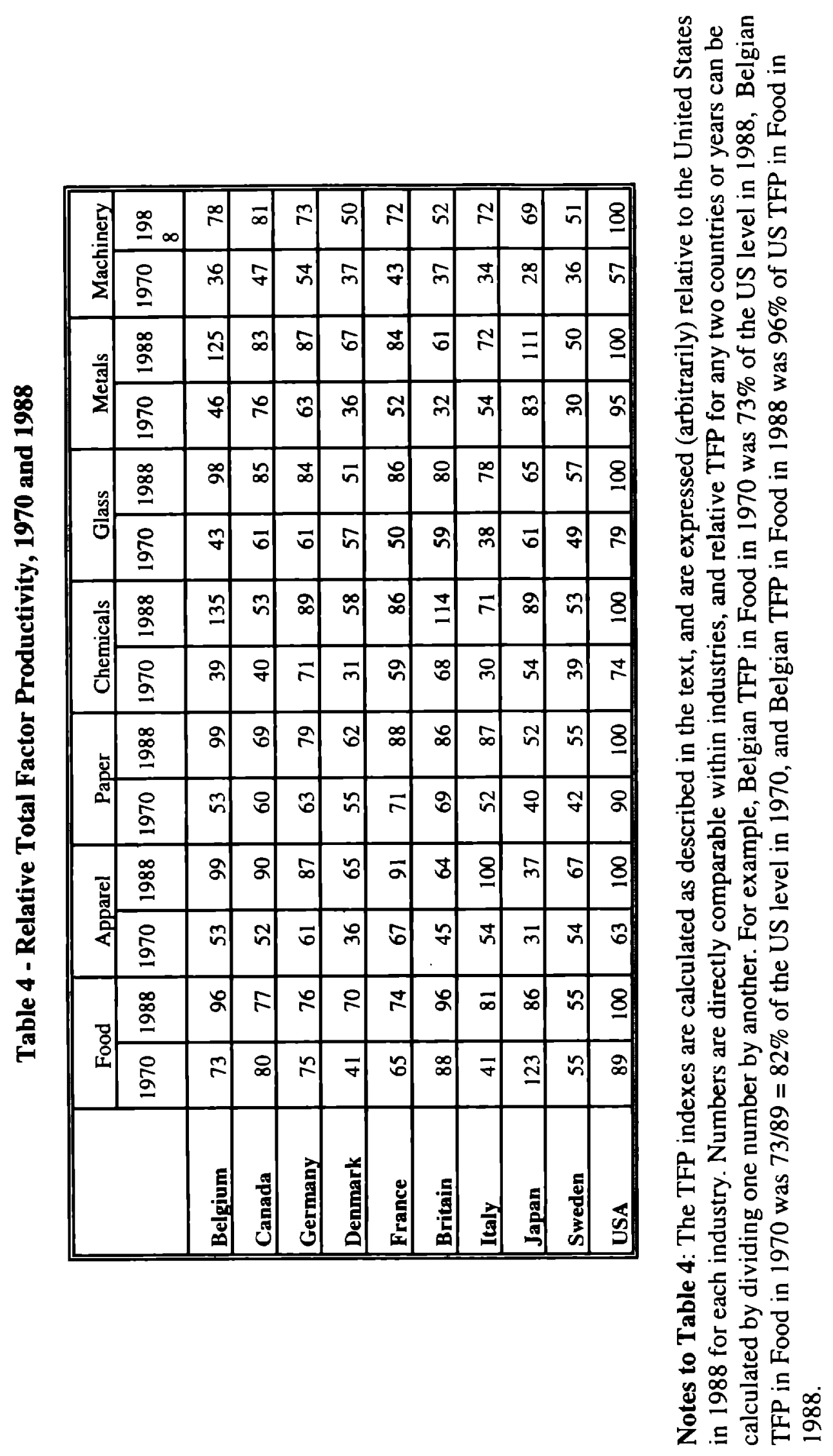







马્ّ

\begin{tabular}{|c|c|c|c|c|c|c|c|c|c|c|c|c|c|c|}
\hline \multirow{2}{*}{ 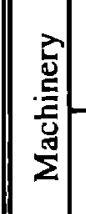 } & 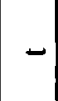 & $\stackrel{\text { Tִ }}{T}$ & $\stackrel{8}{9}$ & $\frac{5}{0}$ & $\stackrel{\circ}{i}$ & & $\begin{array}{l}\text { E } \\
0\end{array}$ & ğ & $\stackrel{\vec{n}}{\frac{n}{1}}$ & ষ্ণ & $\stackrel{\infty}{\underset{\gamma}{+}}$ & $\begin{array}{l}\infty \\
0 \\
0\end{array}$ & $\underset{I}{I}$ & o. \\
\hline &  & 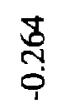 & $\frac{F}{0}$ & $\frac{m}{\sigma}$ & $\underset{T}{\tilde{g}}$ & $\begin{array}{l}\text { 옹 } \\
\text { : }\end{array}$ & $\frac{q}{\square}$ & $\begin{array}{l}\infty \\
0 \\
\text { o } \\
\text { in }\end{array}$ & 음 & $\begin{array}{l}\stackrel{8}{\circ} \\
\text { n̊ } \\
0\end{array}$ & $\begin{array}{l}\hat{\gamma} \\
\text { } \\
\text { ô }\end{array}$ & $\begin{array}{l}\bar{\sigma} \\
\stackrel{5}{0} \\
\dot{\varphi}\end{array}$ & $\begin{array}{l}\hat{D} \\
\stackrel{n}{0}\end{array}$ & 点 \\
\hline
\end{tabular}

至

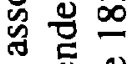
๖ 옹

ปัํํㄴ

๖妿F

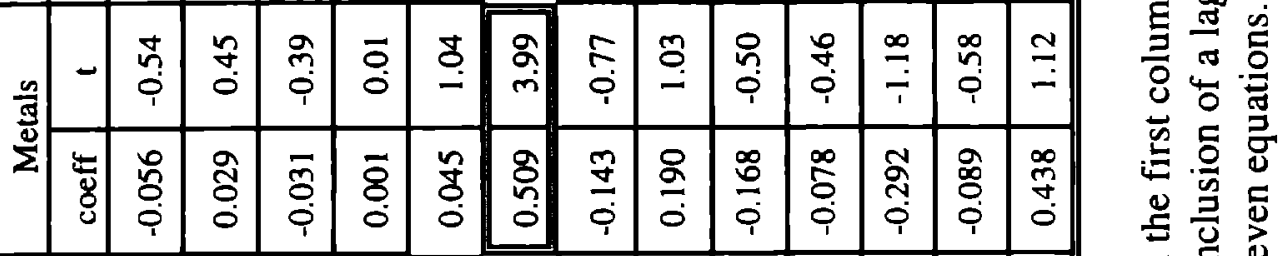

Eิ

\begin{tabular}{|c|c|c|c|c|c|c|c|c|c|c|c|c|c|c|}
\hline & - & $\frac{P}{i}$ & $\stackrel{\circ}{\circ}$ & 草 & $\stackrel{\infty}{\underset{r}{r}}$ & $\begin{array}{c}q \\
\dot{q} \\
\end{array}$ & $\stackrel{+}{-}$ & 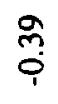 & $\stackrel{\infty}{n}$ & $\stackrel{8}{\circ}$ & $\frac{9}{7}$ & $\stackrel{\text { 구 }}{i}$ & $\begin{array}{l}8 \\
\text { \& } \\
0\end{array}$ & $\stackrel{m}{\Xi}$ \\
\hline & 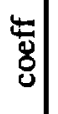 & $\frac{m}{\dot{q}}$ & $\stackrel{m}{\dot{8}}$ & 응 & \%ọ & \begin{tabular}{l}
$n$ \\
\multirow{2}{0}{} \\
0
\end{tabular} & đั & $\begin{array}{l}\text { 웅 } \\
\text { i }\end{array}$ & g. & $\stackrel{8}{8}$ & $\frac{\mathbb{8}}{0}$ & $\stackrel{N}{\rightrightarrows}$ & ষ্ণ & $\frac{8}{0}$ \\
\hline & - & $\bar{i}$ & $\frac{0}{T}$ & @ọ & $\begin{array}{l}a \\
0 \\
0\end{array}$ &  & 웅 & 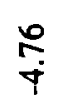 & $\stackrel{\infty}{\infty}$ & $\stackrel{\infty}{=}$ & $\begin{array}{l}\text { ֶু } \\
\stackrel{i}{1}\end{array}$ & $\begin{array}{l}n \\
0 \\
0\end{array}$ & $\begin{array}{l}\text { ָุ } \\
\text { }\end{array}$ & $\begin{array}{l}n \\
\hat{n} \\
i\end{array}$ \\
\hline & 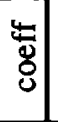 & $\begin{array}{l}8 \\
8 \\
\\
\end{array}$ & $\begin{array}{l}\hat{0} \\
0 \\
\end{array}$ &  & ڤ్తి & ஜे & $\stackrel{\overline{8}}{\circ}$ & $\frac{0}{8}$ & $\stackrel{?}{\frac{R}{2}}$ & $\underset{8}{Z}$ & $\begin{array}{l}\text { 苂 } \\
\stackrel{9}{9}\end{array}$ & $\frac{\infty}{\stackrel{\infty}{i}}$ & 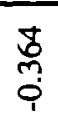 & $\begin{array}{l}\text { స్ } \\
\text { ฺ̣ }\end{array}$ \\
\hline $\bar{\Xi}$ & - & ్ㅗㅇ & $\frac{7}{0}$ & $\stackrel{\overbrace{}}{\text { ฺุ }}$ & ợ & \begin{tabular}{l}
0 \\
\multirow{0}{*}{} \\
0
\end{tabular} & స్ & $\frac{F}{0}$ & $\stackrel{?}{7}$ & å & $\frac{r}{i}$ & $\frac{m}{\dot{\varphi}}$ & $\frac{5}{1}$ & $\stackrel{9}{-1}$ \\
\hline & 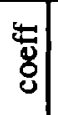 & $\begin{array}{l}\stackrel{\infty}{0} \\
\stackrel{0}{0}\end{array}$ & $\stackrel{m}{\circ}$ & 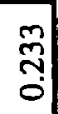 & $\begin{array}{l}8 \\
\text { \&̊ } \\
\end{array}$ & ồ & হ̄ọ & $\frac{m}{0}$ & $\frac{5}{9}$ & ণ্ণু & $\begin{array}{l}\text { ণ্ } \\
\text { ị }\end{array}$ & $\frac{n}{0}$ & $\begin{array}{l}0 \\
0 \\
0\end{array}$ & 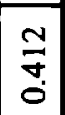 \\
\hline$\overline{\mathrm{g}}$ & -1 & ñ. & $\overrightarrow{\mathrm{i}}$ & $\frac{\mathfrak{N}}{0}$ & $\stackrel{?}{T}$ & 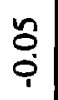 & 年 & $\stackrel{8}{\circ}$ & $\stackrel{+}{\stackrel{9}{-}}$ & $\stackrel{8}{\circ}$ & $\frac{n}{i}$ & $\stackrel{\text { m. }}{i}$ & $\stackrel{f}{0}$ & $\frac{0}{0}$ \\
\hline 4 & 悹 & 乌ั & กิ & $\frac{m}{0}$ & $\frac{5}{i}$ &  & ఫ్రి & $\frac{\xi}{0}$ & 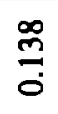 & 훙 & $\begin{array}{l}\text { đ̊̀ } \\
\text { ọ }\end{array}$ & đั & $\stackrel{\infty}{\circ}$ & $\begin{array}{l}\infty \\
0 \\
0 \\
0\end{array}$ \\
\hline & - & $\frac{m}{i}$ & $\stackrel{n}{n}$ & ণ্ণ & $\overline{0}$ & $\frac{?}{?}$ & $\begin{array}{l}\text { ڤ̆ } \\
\text { ọ }\end{array}$ &  & $\stackrel{8}{g}$ & $\underset{\text { ָ̇ }}{\text { in }}$ & $\stackrel{\text { đ̆ }}{0}$ & $\stackrel{\text { ஸ̆ }}{0}$ & $\stackrel{n}{m}$ & $\begin{array}{l}0 \\
\infty \\
i \\
i\end{array}$ \\
\hline & 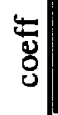 & $\begin{array}{l}\infty \\
n \\
\vdots \\
0\end{array}$ & 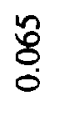 & 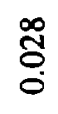 & 客 & $\frac{m}{\dot{g}}$ & ஜ̊ํㅇ & $\begin{array}{l}\text { ț } \\
\text { † }\end{array}$ & ণ্ণ & $\frac{p}{\stackrel{2}{0}}$ & 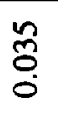 & $\frac{n}{0}$ & $\begin{array}{l}\infty \\
\text { di } \\
\text { i }\end{array}$ & 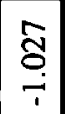 \\
\hline & & 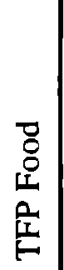 &  & 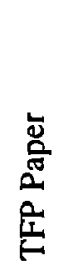 & 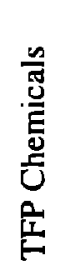 & 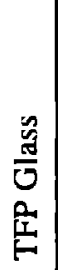 & 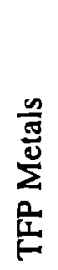 &  & 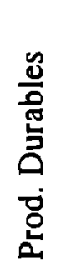 & $\begin{array}{l}\vec{n} \\
\overline{0} \\
\dot{0} \\
\dot{0} \\
\alpha \\
\dot{0} \\
\dot{0}\end{array}$ & 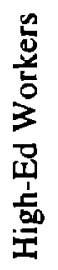 & 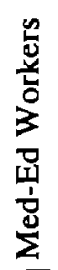 & 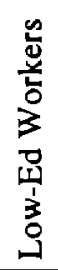 & 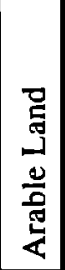 \\
\hline
\end{tabular}

․ㅡ

过

릉ㅇㅇ

品的

总高

는

ชั

过



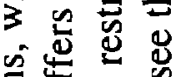

요

结

응

ชี สิ

Чั.

参

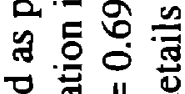



矛造

岁造 跑

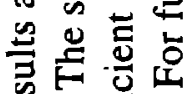

హ

ธ

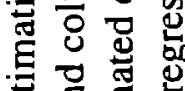

踊氜

虫

U.

可

용

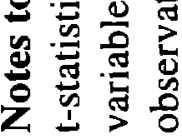






꼴

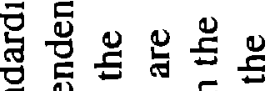

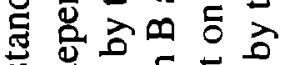
के

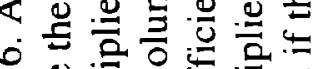
剀造远 ฮ

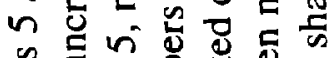

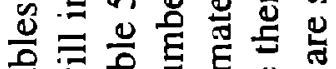

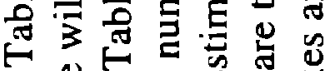


.

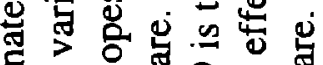


के 응

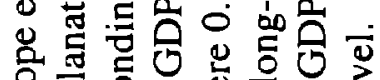
的文 웅


ड

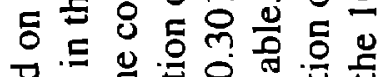

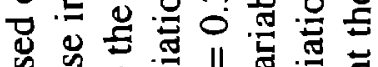
政

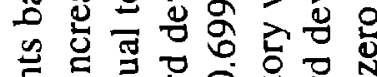


옹

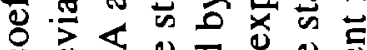

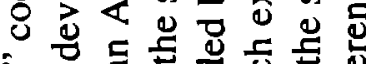

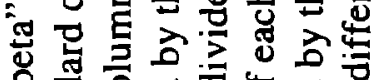

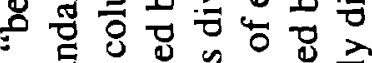

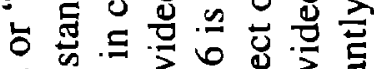
过

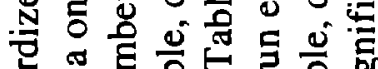

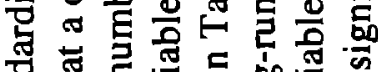
를 밴

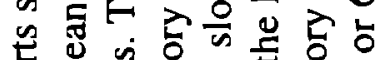
당 㟧 券


중 क्षे

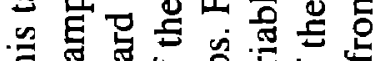

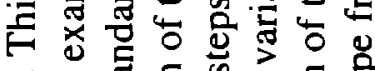
r然

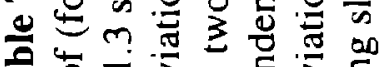

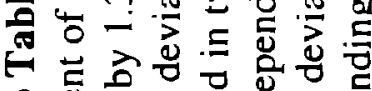


记

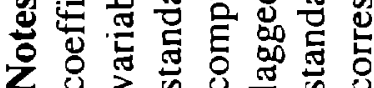




\section{Table 8 - Hypothesis Tests}

Panel A: No lagged dependent variable, equation (5), Table 5

A1. symmetry of cross-TFP effects: $\quad 0.000$

\begin{tabular}{||l|c|r|r|r|r|r|r|r||}
\hline & \multicolumn{1}{|c|}{ Food } & \multicolumn{1}{|c|}{ Apparel } & \multicolumn{1}{|c|}{ Paper } & Chemicals & \multicolumn{1}{c|}{ Glass } & Metals & Machinery & All \\
\hline A3. Homogeneity & 0.471 & 0.498 & 0.823 & 0.290 & 0.512 & 0.308 & 0.098 & 0.041 \\
\hline Significance tests (conditional on Al and A3 imposed) \\
\hline A4. TFP & 0.000 & 0.000 & 0.000 & 0.000 & 0.000 & 0.000 & 0.000 & 0.000 \\
\hline A5. Factors & 0.000 & 0.000 & 0.019 & 0.000 & 0.000 & 0.000 & 0.000 & 0.000 \\
\hline A6.TFP \& Factors & 0.000 & 0.000 & 0.000 & 0.000 & 0.000 & 0.000 & 0.000 & 0.000 \\
\hline
\end{tabular}

Panel B: Lagged dependent variable, equation (7), Table 6

B 1. symmetry of cross-TFP effects: $\quad 0.019$

B2. equality of lagged effects: $\quad 0.000$

\begin{tabular}{||l|r|r|r|r|r|r|r|r|}
\hline \hline & Food & Apparel & Paper & Chemicals & \multicolumn{1}{c|}{ Glass } & Metals & Machinery & All \\
\hline B3. Homogeneity & 0.026 & 0.230 & 0.224 & 0.975 & 0.138 & 0.002 & 0.112 & 0.001 \\
\hline \multicolumn{8}{|l|}{ Significance tests (conditional on B1, B2, and B3 imposed) } \\
\hline B4. TFP & 0.086 & 0.227 & 0.638 & 0.000 & 0.004 & 0.013 & 0.000 & 0.000 \\
\hline B5. Factors & 0.025 & 0.109 & 0.068 & 0.030 & 0.071 & 0.623 & 0.009 & 0.000 \\
\hline B6.TFP \& Factors & 0.021 & 0.076 & 0.177 & 0.000 & 0.008 & 0.009 & 0.000 & 0.000 \\
\hline
\end{tabular}

Notes to Table 8: This table reports the marginal significance levels of hypothesis tests of the specifications reported in the previous two tables. Each test is calculated by computing the appropriate Wald statistic, which has a $\chi^{2}$ distribution with degrees of freedom equal to the number of restrictions being tested.

A1, B1 Hypothesis: cross-TFP effects are equal, $a_{k j}=a_{j k}, k, j=1, \ldots, 7, I \neq j$, which

B2 Hypothesis: coefficients on lagged dependent variables are equal, $\lambda_{\mathrm{j}}=\lambda_{\mathbf{k}}, \mathrm{j}, \mathrm{k}=$ $1, \ldots 7$, which amounts to 6 cross-equation linear restrictions. The test statistic is $\chi^{2}$ (6).

A3, B3 Hypothesis: sum of the factor endowment terms is zero. For each industry separately, the test statistic is $\chi^{2}(1)$. For the hypothesis that homogeneity holds for all seven industry, the statistic is $\chi^{2}(7)$

A4-6, B4-6 Hypothesis: The indicated coefficients are all zero. For each industry separately, the test statistics are
A4, B4:
$\chi^{2}(7)$
A5, B5:
$\chi^{2}(5)$
A6, B6:
$\chi^{2}(12)$

For all seven industries together, the test statistics are

$\begin{array}{ll}\text { A4, B4: } & \chi^{2}(49) \\ \text { A5, B5: } & \chi^{2}(35) \\ \text { A6, B6: } & \chi^{2}(84)\end{array}$


Table 9 - Comparison of Predicted and Actual GDP Shares

\begin{tabular}{||l|ccc|c|c|r||}
\hline \multirow{3}{*}{ Industry } & \multicolumn{4}{|c|}{ Predicted values from Equation (5) } & \multicolumn{3}{|c|}{ Predicted values from Equation (7) } \\
\cline { 2 - 8 } & corr. & intercept & slope & corr. & intercept & \multicolumn{1}{c|}{ slope } \\
\hline Food & 0.285 & 0.098 & 0.144 & 0.659 & -0.044 & 0.417 \\
& & $(1.52)$ & $(4.22)$ & & $(-0.88)$ & $(12.10)$ \\
\hline Apparel & 0.315 & 0.116 & 0.288 & 0.976 & -0.041 & 1.168 \\
& & $(1.74)$ & $(4.71)$ & & $(-2.67)$ & $(62.1)$ \\
\hline Paper & 0.378 & -0.046 & 0.682 & 0.886 & -0.006 & 0.764 \\
& & $(-0.89)$ & $(5.78)$ & & $(-0.22)$ & $(26.42$ \\
\hline Chemicals & -0.323 & 0.182 & -0.306 & 0.933 & -0.024 & 0.953 \\
& & $(1.96)$ & $(-4.83)$ & & $(-0.67)$ & $(35.9)$ \\
\hline Glass & 0.521 & 0.059 & 0.698 & 0.768 & -0.012 & 0.944 \\
& & $(2.30)$ & $(8.66)$ & & $(-0.62)$ & $(16.6)$ \\
\hline Metals & -0.235 & -0.033 & -0.296 & 0.698 & -0.033 & 0.941 \\
& & $(-0.54)$ & $(-3.43)$ & & $(-0.72)$ & $(13.5)$ \\
\hline Machinery & 0.339 & 0.170 & 0.457 & 0.742 & -0.005 & 0.960 \\
& & $(0.96)$ & $(5.10)$ & & $(-0.04)$ & $(15.3)$ \\
\hline \hline
\end{tabular}

Notes to Table 9: Fitted values $S_{\mathrm{jcc}}$ are formed by applying the estimated coefficients from Tables 5 and 6 to the explanatory variables after each explanatory variable has had time means removed. Actual GDP shares $S_{\mathrm{jct}}$ also have time means removed. Time means are removed by keeping the residuals from regressions of each variable on the set of year dummies. The column "corr" reports the correlation between $S_{\text {jct }}$ and $S_{\text {jct }}$ for each industry $j$, and the columns "intercept" and "slope" report the estimated coefficients and t-statistics from the regression of $S_{j \mathrm{jc}}$ on $S_{\mathrm{jc}}$ for each industry $\mathrm{j}$. 